\title{
性別分業意識の多元性とその規定要因
}

\section{The Multiple Dimensions of the Attitudes of Gendered Division of Labor and Its Determinants}

\author{
西 村 純 子 \\ NISHIMURA Junko
}

Previous researches have indicated that attitudes concerning the gendered division of labor are multi-structured. This paper further investigates this point and finds that the attitudes concerning the gendered division of labor has three dimensions: attitudes concerning the gendered division of labor in the narrow sense; norms of love; and a sense of 'good' child care. The determinants for each dimension are explored. The results indicate that the rigidity of the gendered division of labor in Japanese society is supported by strong pressure for 'good' child care.

\section{1.はじめに}

「男は仕事、女は家庭」という最も狭義の性別分業意識は、1970年代半ば以降流動化の 傾向にある(1)。しかしそれにも関わらず性別分業の実態には大きな変化は見られていない。 そうした意識と実態のズレを説明することは、近年の性別分業研究の大きな課題であった といえる。性別分業の意識と実態とのズレには、二つの側面があるだろう。第一に意識が 流動化したにも関わらず、女性の多くは一時的にであれ専業主婦になるということ、第二 に意識の流動化にも関わらず、家庭内での家事・子育ては女性によって担われているとい うことである(2)。

第一のズレは、その原因を労働市場の硬直性に求めることで説明可能である。「男は仕 事、女は家庭」という意識が流動化してもその実態に変化が見られないのは、女性が就業 を継続しにくい労働市場が存在し続けているからだという考え方である。たとえ女性が就 業継続を希望していたとしても、硬直的な労働市場はそれを許さず、そうした状況を合理 化するために女性自らの意識を変容させるような力をもっていさえもする(3)。女性の労働 市場への参入が、「男は仕事、女は家庭」という意識を流動化させうることは、多くの先 行研究で実証されてきた（[原・肥和野 1990:173-174] [木村 1996:128-129][尾嶋 1998:910][山口 1999:98-100][島 1999:31][木村 2000:182-183]など)。しかし女性に開かれている 労働市場は、大きくは若年者用のフルタイム市場と既婚者用のパートタイム市場に分断さ れており、女性の多くは一時的にであれ専業主婦にならざるをえないような構造をもって いる。

しかし第二のズレは、労働市場の要因だけでは説明が難しい。女性はたとえ就業してい たとしても、家事・子育ての大部分を担っている(4)。妻が常勤のとき夫の家事参加が高ま るという知見もあるが、それはある特定の層に限られており、女性の就業によって必ずし も夫の家事参加が高まるわけではない[岩井・稲葉 2000:203-204]。女性の労働市場への参 
入は、必ずしも家庭内での性別分業を流動化させてはいないようだ。

こうした第二のズレを説明する方法として、性別分業をめぐる意識の多元性に着目する アプローチがある。このアプローチは、「男は仕事、女は家庭」という狭義の性別分業意 識は流動化したが、女性を家事・子育てにわりあてる性別分業の意味の体系は、かたちを 变えて維持されているという立場をとる。女性が労働市場へ参入しても、女性と家事・子 育てを結びつけるような意味の体系は、摇らぐことなく女性に家事・子育てをわりあて続 ける。本稿もまたこうした性別分業意識の多元性に着目する立場をとる。本稿では性別分 業意識を広い意味での「女性と家事・子育てを結びっけるような意識」としてとらえ、女 性が労働市場に参入したとしても変わりにくい、性別分業構造の「硬さ」を支える意味の 体系とそのメカニズムを明らかにする。

\section{2. 先行研究と仮説}

\section{（1）性別分業意識の構造についての仮説}

性別分業に関する実証的研究には、大きく分けて意識に注目するものと行動に注目する ものがある。そのうち意識に注目する近年の研究では、性別分業意識の多元性に焦点があ てられている。大和[1995]・島[1999]では、性別分業が性によって役割を振り分けるとい う論理だけではなく、女性による家事・子育て＝愛情という論理によっても支えられてい ることが実証されている。また山田・瀬地山[1988:69-70]では、好きか嫌いかによって役割 を配分する「志向性」(5)という、一見性別とは無関係な原則が働いていることが明らかに されている。つまり性別分業意識の多元性に注目する先行研究からは、性別分業意識の 3 つの次元が導かれる。すなわち、(1)狭義の性別分業意識（性別という論理によって役割分 業が判断される次元)、(2)愛情規範（女性が家事や子育てをおこなうことに愛情という意 味を付与すること)、(3)志向性（家事や子育てが「好きか嫌いか」で判断される次元）で ある。

一方、行動に注目する研究一その代表的なものとして夫の家事・育児参加研究一では、 夫の家事・育児参加にはそれぞれ異なる要因が作用しており（[稲葉 1998:41] [松田 2000:141-143]、家事と子育ては家庭内役割の比較的独立した領域であることが示唆されて いる。こうした知見からは、上で示した性別分業意識の 3 つの次元にも、家事／子育てと いうそれぞれ独立しうる $2 つ の$ 領域があると考えられる。つまり性別分業を支える意味の 体系には、分析的に図-1で示寸ような 6 つの領域がありうる。本稿ではそれらが女性の 意識においてどのような構造を形づくっているかを明らかにしていく。

\begin{tabular}{c|c|c|c} 
& 狭義の性別分業意識 & 愛情規範 & 志向性 \\
\hline 家事の領 域 & (1) & (2) & (3) \\
\hline 子育ての領域 & (4) & (5) & (6)
\end{tabular}

図一1＼cjkstart性別分業を支える意味の 6 つの領域 


\section{（2）性別分業意識の規定要因についての仮説}

本稿では性別分業意識の規定要因として、社会的地位変数（個人の階層構造上の位置） に注目する。社会的地位とは「個人の各種の社会行動（チャンス）を規定するところの属 性で、他の個人・集団・社会との直接的・間接的社会関係の如何によって基礎づけられる もの」[安田 1971:51-52]である。つまり、どのようなチャンスに開かれた人がどのような 意識をもつかという、構造の規定性を問うのである。

性別分業意識の規定要因として社会的地位変数に注目したこれまでの研究は、二つの観 点からおこなわれてきたといえる。つまり女性個人の社会的地位の効果と、世帯内要因の 効果の検討である。これら二点はそれぞれ、性別分業意識の流動化仮説と固定化仮説に対 応してきた。そして女性個人の社会的地位の効果が、世帯内要因の効果を抑えて性別分業 意識を流動化させるようになることが期待されてきたのである。

性別分業意識の流動化仮説は、女性個人の社会的地位の効果に注目してきた。そこで主 に検討されてきたのは、女性の労働市場への参入と学歴の効果である。労働市場への参入 の効果は、性別分業意識が女性の就業に影響を与えるのではなく、就業することによって 性別分業意識は変化しうるという立場から重視されてきた要因である。それはパネル調査 によって実証されてもいる[Thornton and Freedman 1979:836-839]。また学歴（教育）は 「その取得の過程で現状に対する批判的な価值観を身につける」[天野 1988:52]という社会 化効果をとおした、性別分業変革のための重要な戦略として位置づけられてきた。学歴は 確かに、性別分業意識と負の関連をもつ（つまり学歴が高いと性別分業に否定的である） ことが多くの研究によって示されてきた（[原・肥和野 1990:173-174] [大和 1995:118-119] [木村 1996:128-129] [吉川1998:61-62][尾嶋 1998:9-10][山口 1999:98-99][木村 2000:182-183] など)。しかし近年、学歴の社会化効果については疑問が出されている。教育を通した予 期的社会化の効果は結婚後には衰退する[尾嶋 1998:13]ことや、高等教育を受けることに よって性別分業に否定的になるというよりもむしろ、もともと性別分業に否定的な人が高 等教育を受けようとする[木村 1996:130]ことが実証されている。さらに学歴が、性別分業 をめぐる意識を固定化するような効果をもちうることを示唆する研究もある。子どもへの 期待は高学歷女性ほど高いという議論[山田2000:73-76]であるが、これに関しては後に再 度言及する。

性別分業意識の固定化仮説は、世帯内要因に注目してきた。配偶者の職業的地位や世帯収 入の高さは、性別分業に肯定的な態度と親和的であると想定される。これは直井道子の論じ る「借用モデル」の考え方 [直井 1990:147] に基づく。つまり女性の性別分業意識は、配偶 者の社会的地位に規定されるものであるとされる。配偶者の職業的地位や世帯収入が高いと き、女性の就業の必要性は相対的に低くなるため、性別分業に肯定的な態度をとりやすいと 考えられる。借用モデルで重要なのは、性別分業意識を規定しているのは女性が就業してい るかどうかではなく、就業の必要性であるという点である。借用モデルのひとつのバージョ ンとして、山田昌弘の議論がある。山田は、夫に依存して高い生活水準を享受している女性 ほど子どもへの期待が高いと論じる[山田 2000:76]。期待の強さは、女性の子育てへの高い コミットメントを動員するが、そうした傾向が強いのは、夫に経済力があるために専業主婦 でいられ、かつ競争して成果をあげることにアイデンティティを求めるような、高学歴専業 主婦であるという。つまり高学歴専業主婦は、女性と子育てを結びつけるような意識をもち 
やすいと考えることができる。これを高学歴専業主婦仮説と呼ぼう。

これらの議論から、本稿の分析で焦点をあてるべき点は次のように整理できる。すなわ ち性別分業に対する、(1)女性の就業の流動化効果の検証／(2)学歴の効果の解明／(3)世帯内 要因の固定化効果の検証／(4)高学歴専業主婦仮説の妥当性の検討、である。本稿ではこう した諸点が、性別分業意識の多元的な側面とどのように関わっているかを明らかにするこ とを通して、性別分業を意味のうえで支えるメカニズムについて考察をおこなう。

\section{3. データ}

本稿の分析は、1999年10 11月に東京都大田区・品川区に在住する25 64歳の女性を対象に おこなった質問紙調査から得られたデータを用いる。住民基本台帳より無作為に1437名を抽 出、調査は郵送法でおこない、回収票数336票、転居先不明等を除いた回収率は23.6\%(6)であ った。今回の分析は、回収された票のうち配偶者をもつ者 260 名についておこなっている。

分析対象者の主な属性は以下の通りである。年齢は、25 29歳 $(6.6 \%) 、 30 ~ 39$ 歳 $(19.3 \%) 、$ 40 49歳 $(34.0 \%) 、 50 ~ 59$ 歳 $(30.1 \%) 、 60 ~ 64$ 歳（10.0\%）である。就業形態は、就業していな

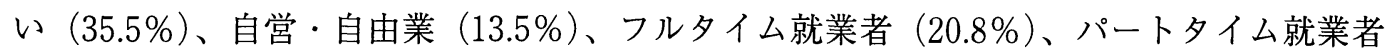
$(29.0 \%) 、 そ の$ 他 $(1.2 \%)$ となっている。最終学歴は、中学校 $(5.0 \%) 、$ 高校 $(38.6 \%) 、$ 短

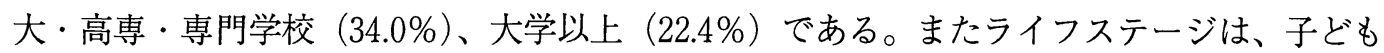
なし $(14.7 \%)$ 、末子小学校入学前 $(14.7 \%)$ 、末子小学校 $(16.3 \%) 、 末 子$ 学校・高校 (19.4\%)、末子短大・高専・専門学校・大学 $(10.9 \%)$ 、教育終了 $(24.0 \%)$ となっている。

性別分業意識（女性と家事・子育てを結びつけるような意識）の指標とその分布を表一 1 に示す。(1) (5)は狭義の性別分業意識、6) (10)は愛情規範、(11) (144は志向性を想定して設 定した。3つのそれぞれの側面について、家事に関する項目と子育てに関する項目を別々 に設定している。各指標とも、そう思う $=4$ 点、どちらかといえばそう思う $=3$ 点、どち らかといえばそう思わない $=2$ 点、そう思わない $=1$ 点の 4 点尺度で測定した。

\section{表ー1 分析に用いた指標とその記述統計量}

\begin{tabular}{|c|c|c|c|}
\hline & $\mathrm{N}$ & 平均 & S. D. \\
\hline (1)男は外で働き、女は家庭を守るべきである & 260 & 1.72 & 0.87 \\
\hline (2)子育ての責任は母親がもつべきである & 255 & 2.27 & 1. 01 \\
\hline (3)妻は家事に責任をもつべきである & 258 & 2.70 & 0.95 \\
\hline (4)できることなら仕事はもたず、専業主婦でいたい & 259 & 1.95 & 1.03 \\
\hline (5)夫にも家事を責任をもってやってほしい（逆スコア） & 257 & 2. 11 & 0.93 \\
\hline (6)家族の食事は愛情をこめてつくるべきである & 258 & 3.50 & 0.65 \\
\hline (7)家の中のことは、すべて自分でわかっているようにしておきたい & 258 & 3. 35 & 0.82 \\
\hline 88親は子どもにできるだけのことをしてやるべきである & 256 & 3. 26 & 0.83 \\
\hline (9)子どもは母親の愛情がなければうまく育たない & 257 & 3.35 & 0.81 \\
\hline (10)どもをかわいがることのできる親だけが、子どもをもつべきである & 258 & 2. 75 & 1.05 \\
\hline (11)家事をするのはおもしろい & 257 & 2. 61 & 0.81 \\
\hline (12)家事をすると気持ちがさっぱりする & 258 & 3. 01 & 0.89 \\
\hline (13)子育ては楽しいことだ & 257 & 3.28 & 0.79 \\
\hline (14)子育てはやりがいのあることだ & 257 & 3.45 & 0.72 \\
\hline
\end{tabular}


分析は、次の 4 節で性別分業意識の構造の多元性を検証し、5 節でそれぞれの次元につ いて社会的地位変数との関連を明らかにするという手順をふむ。

\section{4. 性別分業意識の構造}

\section{（1）因子分析}

まず設定した14の指標すべてを用いて探索的因子分析をおこなったところ、固有値 1.0 以上の因子が 5 つ得られた。その第 1 因子の寄与率は $13.69 \%$ ああり、累積寄与率は 60.53\%であった。この結果は、累積寄与率はかろうじて $60 \%$ に達しているものの、因子 の数が 5 つと比較的多く、第1因子の寄与率もそう高くない。そこで指標の独立性を考慮 し、互いに相関の強い指標に関してはその一方を除外して再度分析をおこなった。具体的 には、(1)と (4)、(11)と (12)、(13)と(14)は相関係数が概ね0.4以上であったため、(4)、(12)、(14)は除 外して再度探索的因子分析をおこなった。その結果 3 つの因子が得られ、第1因子の寄与 率は $17.48 \%$ 、累積寄与率は $49.00 \%$ となった（結果は表－ 2 に示す）。これは先の分析結果 と比べて、情報の圧縮という点においてより優れていると判断される。

\section{表 -2 探索的因子分析の結果 (主成分解、バリマックス回転、n=246)}

第 1 因子第 2 因子第 3 因子 共通性

\begin{tabular}{lrrrr}
\hline \hline (1)男は外、女は家庭 & .69 & .05 & .12 & .50 \\
(2)母親子育て責任 & .63 & .04 & .23 & .46 \\
(3)妻家事責任 & .60 & .39 & .19 & .55 \\
(5)夫家事責任 & .71 & .13 & -.22 & .57 \\
(6)食事愛情 & .07 & .76 & .08 & .59 \\
(7)わかっていたい & .15 & .47 & .31 & .34 \\
(8)できるだけのこと & .27 & .06 & .63 & .48 \\
(9)愛情なければ & .17 & .32 & .49 & .37 \\
(10かわいがれる親だけ & -.07 & -.05 & .76 & .59 \\
(11)家事おもしろい & .20 & .69 & -.16 & .54 \\
(13)子育て楽しい & -.07 & .48 & .42 & .41 \\
\hline 固有值 & 1.92 & 1.78 & 1.68 & 5.40 \\
寄与率 (\%) & 17.48 & 16.18 & 15.31 & 49.00 \\
\hline
\end{tabular}

注 : 絶対值が 0.4 以上の因子負荷量に網排けをほどこしてある。

抽出された因子はそれぞれ、第1因子：狭義の性別分業意識、第 2 因子：愛情規範、第 3 因子：「よい子育て」意識と解釈することができる。第 2 因子は、「家事をするのはお もしろい」「子育ては楽しいことだ」など志向性として設定した指標の因子負荷も大きい。 しかしこの因子は愛情規範と解釈するのが妥当であろう。なぜならこの結果が示している のは、好き/嫌いといった志向性もまた規範から自由ではありえないということであり、 この場合愛情規範と結びっいていると考えられるからである。志向性の論理は確かに狭義 の性別分業意識と異なる次元のものであるが、それはまた愛情規範と密接に結びついてい るのである。家事や子育ては家族への愛情を示す手段である。好きであるほうが愛情をよ り容易に示すことができる。そのため、愛情を示す手段となる家事や子育てを好きになろ 
うとするメカニズムが作動していると考えられる。

また子育て規範ともいえる、「よい」子育てに関する因子が抽出されたことにも注目す べきである。このことから家事と子育ては、行動についてだけでなく規範についても独立 に考察すべき領域であり、性別分業体制下において家事と子育ては、異なる論理で女性に わりあてられているのではないかと考えられる。

このように探索的因子分析の結果から性別分業意識には、狭義の性別分業意識・愛情規 範・「よい子育て」意識という 3 つの次元があることが示されている。しかしながら探索 的因子分析による推定はモデルの自由度が高く、結果も暫定的なものとして位置づけられ る。Joreskog and Lawley [1968:85]で論じられているように、探索的因子分析によって導 かれた仮説は、さらに検証されるべきものであるといえるだろう。そこで本稿では、探索 的因子分析による結果をあらためて確認するために、性別分業意識の11指標に関して確証 的因子分析をおこなった。その結果を図ー2に示す。

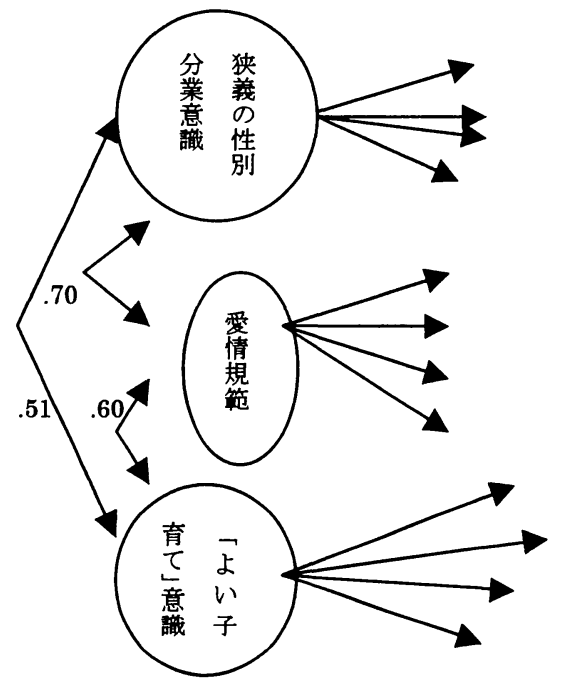

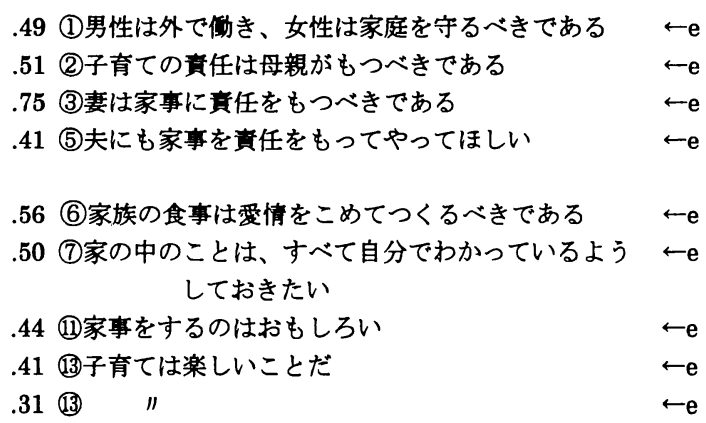

.50 8) 親は子どもにできるだけのことをしてやるべきであるヶe

.60 (9)子どもは母親の愛情がなければうまく育たない ヒe

.35 10子どもをかわいがることのできる親だけが、 $\mathrm{e}$

子どもをもつべきである

\section{$\mathrm{N}=246 \quad \chi^{2}=79.65$ d.f. $=41 \quad \chi^{2} /$ d.f. $=1.94 \quad$ GFI=.95 $\quad$ AGFI=.91 RMR $=.06$ \\ 図-2 性別分嶪意識の測定方程式モデル}

図の下に示した各指標は、モデルの適合度を示している。GFI(Goodness of Fit Index)、 AGFI（Adjusted Goodness of Fit Index）は経験的に0.9以上必要であるとされており、 RMR(root mean square residual)は 0 に近いほどモデルとデー夕の当てはまりがよいとされ る。以上いずれの指標に照らしても、この測定モデルの適合度は十分によいといえる。

因子間の相関係数は $0.5 \sim 0.7$ の值を示している。これは例えば狭義の性別分業意識と愛 情規範の分散の重なりが $49 \%$ にすぎず、それぞれを別の概念として規定することが可能で あることを意味している。むろん一般に社会調査において概念間に 0.5 以上の相関係数が 得られるとき、分散の重なりが50\%に満たないとはいえ、それは非常に高い值である。こ れら性別分業意識の各次元が非常に近いものであるにも関わらず、多元的にとらえること が妥当であるかどうかについては、次節の議論をふまえて結論を得たい。 


\section{5. 性別分業意識の規定要因}

\section{（1）用いた変数}

前節の確証的因子分析で測定された 3 つの潜在変数（狭義の性別分業意識、愛情規範、 「よい子育て」意識）を従属変数として、社会的地位変数との関連を明らかにする。

独立変数は、 2 節で論じた仮説に対応して次の 4 变数を設定した（カッコ内に操作化の 方法を示す）。すなわち、学歴（教育年数）、家計参入度（本人収入の値を世帯収入で除す。 本人収入、世帯収入は、収入なし $=0 、 50$ 万円未満 $=25 、 50 \sim 100$ 万円未満 $=75 、 100 \sim 200$ 万円未満＝150、200 300万円未満＝250のように数值を与える。1500万円以上は 1500 とす る)、配偶者の職業的地位（本調查で測定された $5 つ の$ 職業カテゴリーごとに、1995年 SSM調査によって得られた職業威信スコアの平均値を当てる(7)。配偶者が無職の場合は欠 損值扱い)、世帯収入（前述のと扔り）、である。また、コントロール変数として、調查時 点での本人年齢を設定した。各变数の分布状況を表一 3 に示す。

\section{表ー3 分析に用いた変数とその記述統計量}

\begin{tabular}{lccc}
\hline & $\mathrm{N}$ & 平均 & $\mathrm{S} . \mathrm{D}$. \\
\hline \hline 学歴 & 259 & 13.42 & 1.84 \\
家計参入度 & 240 & 0.21 & 0.21 \\
配偶者職業的地位 & 233 & 56.21 & 8.94 \\
世帯収入 & 240 & 866.67 & 352.24 \\
年齢 & 259 & 46.24 & 9.91 \\
\hline
\end{tabular}

\section{（2）重回帰型の構造方程式モデルの検討}

性別分業意識の各次元について、前述の 4 つの変数の効果を検討するために、重回帰型 の構造方程式モデルを構成し、実測值にあてはめた。表一 4 の従属变数に対する独立变数 の効果を表す各係数は、いずれも完全標準化解であり、関係する变数の分散を 1 に規準化 して求めた母数の推定值である。

\section{表-4 性別分業意識を従属変数とする重回帰型の構造方程式モデル}

\begin{tabular}{lrrr}
\hline & 狭義の性別分業意識 & 愛情規範 & 「よい子育て」意識 \\
\hline 学歷 & .07 & -.01 & $.21 *$ \\
家計参入度 & $-.48 *$ & $-.19 *$ & -.07 \\
配偶者職業的地位 & -.09 & .08 & .15 \\
世帯収入 & -.06 & -.13 & .01 \\
年齢 & .13 & .16 & -.15 \\
\hline 決定係数 $\mathrm{R}^{2}$ & .26 & .09 & .12 \\
サンプル数 $\mathrm{N}$ & 205 & 208 & 206 \\
$\chi^{2} /$ d.f. (自由度) & $1.90(22)$ & $1.72(22)$ & $.35(22)$ \\
GFI、AGFI & $.95, .90$ & $.96, .93$ & $.97, .94$ \\
RMR & .05 & .06 & .05 \\
\hline
\end{tabular}

注 : *は $5 \%$ 水準で有意な值を示す。 
まず狭義の性別分業意識について適合度の指標をみると、モデルは実測值によく適合し

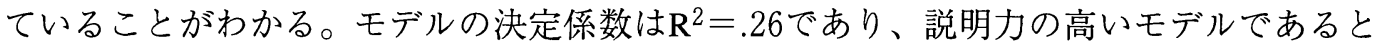
いえる。独立変数の効果をみると、家計参入度が大きな効果をもっており (-.48)、家計 参入度が高いほど性別分業に否定的な傾向がみられる。

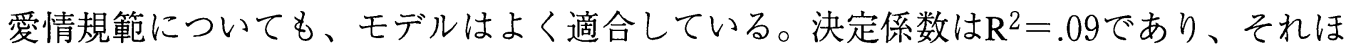
ど高くないが、次のことがいえる。独立変数の効果をみると有意な効果がみられるのは、 家計参入度 (-.19) である。家計参入度が低いほど愛情規範が強い傾向がみられる。

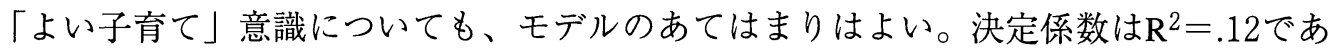
る。独立変数からの効果をみると有意な効果がみられるのは学歴 (.21) である。学歴が 高いほど「よい」子育て意識が強い傾向がみられる。また、統計的有意差はみられないが、 配偶者の職業的地位と「よい子育て」意識には正の関連がみられる。

\section{（3）構造方程式モデルの結果の整理}

先に示した構造方程式モデルの結果を、以下の 3 点にわけてまとめる。

\section{1）女性の経済力の効果}

女性の経済力に注目すると、狭義の性別分業意識と愛情規範について、家計参入度の効果 がみられる。これは女性が就業し経済力を持つことによって、性別分業に否定的な態度が形 成され、愛情にまつわる規範が相対化されうることを示唆している。とりわけ狭義の性別分 業意識に関しては家計参入度の効果が大きく、女性の経済力が決定的な要因であることがわ かる。一方「よい子育て」意識については、女性の経済力は効果をもっていない。

\section{2 ) 世帯要因の効果}

世帯要因に関しては、どの意識次元においても有意な効果はみられない。しかし統計的 有意差はみられないものの、配偶者の職業的地位が「よい子育て」意識と正の関連を示し ているのは注目すべき傾向である。これまで狭義の性別分業意識に関しては、配偶者の職 業的地位との関連は認められてこなかった（[吉川 1998:61-64][山口 1999:106]など）。本 稿の分析結果からは、配偶者の職業的地位は、狭義の性別分業意識ではなく「子育て」を めぐる規範意識と関連しているのではないかという仮説が提示できる。つまり配偶者の職 業的地位の高さは、女性に「よい子育て」へのプレッシャーをかけていると考えられる。

\section{3 ) 学歴の効果}

学歴は「よい子育て」意識にのみ有意な正の関連を示している。狭義の性別分業意識や 愛情規範には関連を示していない。本稿のこうした分析結果は、狭義の性別分業意識や愛 情規範について、就業に先行する学校教育の社会化効果を支持していない。それらの意識 次元が一方では女性自身の経済力に強く規定されていることを加味すると、既婚女性につ いては学校教育による予期的社会化の効果を、参加的社会化の効果（つまり労働市場参入 の効果）が上まわっているという尾島史章[1998:12]の議論を支持するものとなっている。

学歴が影響力をもちうるのは、「よい子育て」をめぐる側面である。「よい子育て」意識 が配偶者の職業的地位と正の関連を示すことをかんがみると、学歴の効果は、「よい子育 て」実践を通して顕在化される、学歴の地位表示機能[天野 1983:44]としての解釈が妥当 ではないかと考えられる。つまり子どもを「よく」育てていることは親としてのステイタ スであり、その学歴にふさわしい象徵的価值をもつと考えられるのである。従来学歴は、 
性別分業意識を流動化させる要因としてとらえられてきた。そして近年、その効果が弱ま ってきていることが指摘されている。本稿の分析結果は、学歷はより積極的に性別分業を めぐる意識を固定化するような効果をもちうることを示しているのである。

\section{6. 議論}

本稿の分析で明らかになったのは、性別分業意識（女性と家事・子育てを結びつけるよ うな意識）は、狭義の性別分業意識、愛情規範、「よい子育て」意識の 3 次元に多元的に とらえられるものであり、それぞれの次元を規定する要因やその影響力が異なっていると いうことである。性別分業意識の 3 次元は、社会的に異なる係留点をもち、性別分業意識 を多元的にとらえることの妥当性が検証された。とりわけ子育ての規範的意識は、愛情規 範や狭義の性別分業意識とは異なる要因によって規定されている。女性が「よい子育て」 をするために子育てに主体的にコミットし、その主たる担当者となっていくような意識を 形成するメカニズムは、家事（や子育て）をすることで愛情を示すことや狭義の性別分業 に関する意識を形成するメカニズムとは異なるものであるといえる。

狭義の性別分業意識や愛情規範は、女性が経済力を持つことによって相対化されうるこ とが見出された。特に狭義の性別分業意識は、女性の経済力に大きく規定される次元であ る。しかし「よい子育て」意識に、女性の経済力は効果をもたない。「よい子育て」意識 の規定要因は学歷であり、高学歷者ほど「よい子育て」意識が強い。これは学歴の地位表 示機能の観点から解釈される。つまり高学歴を取得した女性にとっては、「よい子育て」 をすること（していると信じること）は親としてのステイタスであり、その学歴にふさわ しい象徴的価值をもつと考えられるのである。

こうした結果から検討すると、山田の論じる高学歴専業主婦仮説は修正をせまられる。 山田は、子育てに関する規範的圧力を高学歴専業主婦のアイデンティティ問題として議論 している。しかし本稿の分析結果からは、異なる見解が導かれる。確かに子育てに関する 規範的圧力は高学歷女性に、より強くかかっているといえる。しかしそれは女性の就業状 況（専業主婦か否か）には関連しておらず、就業状況に関わらず女性には子どもを「よく」 育てるプレッシャーがかかることを本稿の分析結果は示している。「よい子育て」をめぐ る規範的圧力は、専業主婦だけの問題ではなく、高学歴女性全体の問題としてとらえられ るべきなのである。そして、拉そらくこのことが女性の二重負担を支えていると考えられ る。女性が労㗢市場へ参入し経済力をもってもなお、家事や子育ての主たる担当者であり 続けるのは、女性が経済力をつけることによっては流動化されえない子育てへの規範的圧 力が働いているからであり、性別分業の変わりにくさはそこにあると考えられる。

以上の議論から、次のような結論を導くことができる。もし今後の日本社会における女 性の労働力化と高学歴化を想定するならば、労働力化による女性の経済力の増大は、狭義 の性別分業意識や愛情規範の相対化をうながし、日本社会の性別分業構造は一定程度流動 化しうると考えることもできる。しかし学歷の地位表示機能は、高い学歴を取得した女性 に、その地位を表示するにふさわしい「よい子育て」への規範的圧力をかける。それは、 女性が子育ての主たる担当者となっていく強力な論理でもありうる。「よい子育て」意識 は、女性が仕事を辞めて子育てを生活の中心に扔くことや、仕事をもちながらも子育ての 中心的な担い手となること、つまり性別分業の実践にも十分な正当性を与えると考えられ 
る。つまり本稿の分析結果からは、性別分業構造の固さを意味のうえで支えるのは、「よ い子育て」への規範的圧力であることが示されている。それは女性の労働市場への参入や 高学歴化によって摇らぐことはなく、むしろ強化されるようなものなのである。むろん 「よい子育て」意識から性別分業が直接的に導かれるわけではないかもしれない。それは 「役割分業」とは異なる次元であり、夫の関与を拒まないという意味で、「協業」の可能性 はある。ただし本稿の分析結果は、少なくとも女性が子育てを手放すことはないこと、役 割の逆転（妻が㗢き、夫が家事育児）はおこりにくいであろうことを示している。高学歷 女性にとっては、「よい子育て」が女性自身の学歴の象徽的価值を示すものとなっている ことは先に論じたと扔りである。「よい子育て」は、それによって女性がアイデンティテ イを確認するものでもあるため、女性が子育てを手放すことは考えにくい。また「よい子 育て」意識は夫の職業的地位とも正の関連を示しており、「よい子育て」は現在の夫の地 位を維持するためのものでもある。夫が現在の地位を維持することは前提条件であるため、 役割の逆転は起こりにくいだろう。結果的に性別分業的なかたち（夫が働き妻が家事育児、 あるいは妻の二重負担）をとりやすいことが想定されるのである。

最後に本稿の限界と今後の課題についてふれておきたい。まず、本稿の分析で用いたデ 一夕が、大都市に居住する女性から得られたものに限定されること、調査の回収率が低い ものにとどまっていることをかんがみると、知見の一般化には一定の留保が必要である。 また、「よい子育て」意識が性別分業を支える重要な軸であるという本稿の知見は、あく まで女性の意識構造の分析を通して導かれたものである。しかしながら性別分業は、男性 との関係性のなかで実践されるものである。男性の性別分業意識は、女性とは異なる構造 をもつという指摘[山口 1998:137]もあり、男性の意識構造との比較、その差異が性別分業 の維持・生成にどのように関わるかについては、今後の課題としたい。

（付記）本研究は1999年度の財団法人家計経済研究所および財団法人東京女性財団によ る研究助成の成果の一部である。なお、本稿は家計経済研究所および東京女性財団へ提出 した報告書の一部を、大幅に加筆・修正したものである。家計経済研究所に提出したもの については西村[2000]として刊行されている。

注

（1）「夫は外で働き、妻は家庭を守るべきである」という意見に賛成する女性は、1972年には48.8\%で あったのが、1997年には17.9\%にまで減少している[厚生省 1998:22]。

（2）女性のM字型就労は現在なお維持されている[岩井・真鍋 2000:72-78]。また1999年に実施された全 国家族調査（NFR98）の結果からも、「食事の用意」「洗濯」などの家事に夫が従事する頻度は非常に 少ないことが指摘されている[岩井 2000:62-63]。

（3）このようなメカニズムを木村邦博[2000:184]は、「労働市場の分断のもとでの合理的選択と認知的不 協和」と説明している。

（4）家庭動向調查（1993年実施）の結果によれば、妻・夫ともに常勤の夫婦のうち、夫の「炊事」の頻 度について「月 $1 \sim 2$ 回程度」「やったことがない」という回答を合計すると60\%以上に達する。「週 1 2 回程度」まで含めると、約 $80 \%$ にもほる（[厚生省人口問題研究所 1996:245]より算出）。

（5）ここで用いる「志向性」とは、山田・瀬地山[1988]の用法にしたがい、好き・嫌いによる個人の判 断を意味する。現象学的な意味での「志向性」(「意識は必ずなにものかについての意識である」と定 式化される意識の特質。人間の経験を成立させる根本的な契機と見なされる）や、パーソンズのパ夕 
ーン変数に代表されるような、個人が社会的行為をおこなう際にしたがう基底的な方向性を示すもの ではない。

（6）回収された標本の年齢構成、有配偶率、就業状況について1995年実施の国勢調査[総務庁統計局 2000]との比較をおこなった。標本の年齢構成、有配偶率は国勢調査の数值とほぼ対応している。従業 上の地位については、標本は自営業の割合は国勢調査の数值とほぼ対応するが、無職（家事従事者） の割合が10\%ほど低く、逆に雇用者（フルタイム・パートタイム含む）の割合が $10 \%$ ほど高くなって いる。また標本の学歴構成を、全国家族調査（NFR;1999年実施。詳しくは日本家族社会学会全国家族 調査（NFR）研究会編[2000]参照。）と比較すると、標本は義務教育、高校がそれぞれ $10 \%$ ほど少なく、 短大が $5 \%$ 強、大学以上が $15 \%$ 強ほど多くなっている。つまり回収された標本は、雇用者、高学歴者に やや偏りがある。また回収率が低い数值にとどまっている以上、本稿で明らかになる因子構造や因子 と社会的地位変数との関連もあくまで暫定的なものとして位置づけたい。

（7） 1995年SSM調査において得られた職業小分類ごとのスコア[都築 1998巻末]をもとに、今回の調査で 測定されている 5 カテゴリーの職種に対して、それぞれの平均値を次のようにわりあてた。管理職… 64.9、事務職 $\cdots 48.6$ 、販売 ・ サービス職 $\cdots 45.9$ 、専門 - 技術職 $\cdots 66.6$ 、技能 - 労務職 $\cdots 47.1$ 。職種カテ ゴリーに職業威信スコアの平均值をわりあてて分析をおこなっているものに林[1997]がある。ただし 林[1997]では、職種を10カテゴリーに分けて分析している。本稿の分析で用いている職種カテゴリー はかなり大まかなものであり、わりあてられている職業威信スコアの平均值は、カテゴリー内の多様 性をかなり捨象した上での、便宜的なものであることを付記しておきたい。

\section{文献}

天野郁夫 1983 「教育の地位表示機能について」日本教育社会学会編 『教育社会学研究』38:44-49. 天野正子 1988 「性と教育』研究の現代的課題一かくされた『領域』の持続」 日本社会学会編 『社 会学評論』39(3)：38-55.

原 純輔・肥和野佳子 1990 「性別役割意識と主婦の地位評価」岡本英雄・直井道子編 『現代日本の階

層構造(4)女性と社会階層』東京大学出版会: 165-186.

林 拓也 1997 「職業的地位とネットワーク特性」東京都立大学都市研究所編 『総合都市研究』64： 25-38.

稲葉昭英 1998 「どんな男性が家事・育児をするのか? 一社会階層と男性の家事・育児参加一」 渡 辺秀樹・志田基与師編 『階層と結婚・家族（1995年SSM調査シリーズ15）』1995年SSM調查研究 会: $1-42$.

岩井八郎・真鍋倫子 2000 「M字型就業パターンの定着とその意味一女性のライフコースの日米比較を 中心に一」盛山和夫編 『日本の階層システム 4 ジェンダー・市場・家族』東京大学出版会 : 67 91.

岩井紀子 2000 「婦関係」日本家族社会学会全国家族調査（NFR）研究会編『家族についての全国 調查（NFR98） No.1』 日本家族社会学会：58-70.

岩井紀子・稲葉昭英 2000 「家事に参加する夫、しない夫」盛山和夫編 『日本の階層システム 4 ジェ ンダー・市場・家族』東京大学出版会 : 193-215.

Joreskog, K.G. and D.N. Lawley. 1968 "New methods in maximum likelihood factor analysis." The British Journal of Mathematical and Statistical Psychology 21(1):85-96.

吉川 徹 1998 「性別分業意識の形成要因 : 男女比較を中心に」尾嶋史章編 『ジェンダーと階層意識 （1995年SSM調査シリーズ14）』1995年SSM調査研究会：49-70.

木村邦博 1996 「女性にとっての学歴の意味一教育・職業と性別役割意識」 鈴木昭逸・海野道郎・片瀬 一男編 『教育と社会に対する高校生の意識—第3次調査報告書一』東北大学教育文化研究会： 121-138.

木村邦博 2000 「労働市場の構造と有配偶女性の意識」 盛山和夫編 『日本の階層システム 4 ジェンダ 一・市場・家族』東京大学出版会：177-192. 
厚生省編 1998 『厚生白書（平成10年度版）少子化社会を考える—子どもを産み育てることに「夢」を 持てる社会を一』ぎょうせい.

厚生省人口問題研究所編 1996 『現代日本の家族に関する意識と実態—第1回全国家庭動向調査（1993

年）—』厚生統計協会.

松田茂樹 2000 「夫の家事・育児参加の規定要因」『年報社会学論集』13：134-145.

直井道子 1990 「階層意識一女性の地位借用モデルは有効か一」岡本英雄・直井道子編『現代日本

の階層構造(4)女性と社会階層』東京大学出版会：147-164.

日本家族社会学会全国家族調査（NFR）研究会編 2000 『家族についての全国調查（NFR98） No.1』日 本家族社会学会.

西村純子 2000「『主婦』をめぐる意識構造」『季刊家計経済研究所』47 財団法人家計経済研究所: 57-72 尾嶋史章 1998 「女性の性役割意識の変動とその要因」尾嶋史章編 『ジェンダーと階層意識（1995年 SSM調查シリーズ14)』1995年SSM調査研究会：1-22.

島 直子 1999 「性別分業を維持する意識構造—『愛情』イデオロギーの視点から一」関東社会学会

機関誌編集委員会編 『年報社会学論集』12:26-37.

総務庁統計局編 2000 『平成 7 年国勢調查最終報告書 日本の人口（資料編）』日本統計協会.

Thornton, A. and D.Freedman. 1979 "Changes in the sex role attitudes of women, 1962-1977: Evidence

from a panel study." American Sociological Review 44(5):831-842.

都築一治編 1998 『職業評価の構造と職業威信スコア』 1995年SSM調査研究会.

山田昌弘 2000 「よりよい子育て』に追い达まれる母親たち」目黒依子・矢澤澄子編『少子化時代の ジェンダーと母親意識』 新曜社：69-87.

山田昌弘・瀬地山角 1988 「性別分業隠蔽のメカニズム一大学生の性役割意識調査からー」家族問題研 究会編 『家族研究年報』14:60-72.

山口一男 1998 「女性における性別役割意識と社会階層、職歴、ライフスタイルとの関連」佐藤嘉倫編

『社会移動とキャリア分析（1995年SSM調査シリーズ 3)』1995年SSM調査研究会：123-155.

山口一男 1999 「既婚女性の性別役割意識と社会階層」日本社会学会編 『社会学評論』50（2）：91-

111.

大和礼子 1995 「性別分業意識の二つの次元一『性による役割振り分け』と『愛による再生産役割』

—」ソシオロジ編集委員会編 『ソシオロジ』40（1）：109-126.

安田三郎 1971 『社会移動の研究』東京大学出版会.

（慶應義塾大学大学院社会学研究科後期博士課程、 